\title{
A NEW MODEL OF CONTINUOUS IMPROVEMENT IN TOTAL QUALITY MANAGEMENT FROM AN ISLAMIC PERSPECTIVE
}

\author{
Afroza Bulbul Afrin', Rafikul Islam ${ }^{2 *}$, Rodrigue Ancelot Harvey Fontaine ${ }^{2}$, \\ Md. Yousuf Ali ${ }^{3}$, and Mizanur Rahman ${ }^{4}$ \\ ${ }^{1}$ Department of Business Administration, Faculty of Business Studies, International \\ Islamic University Chittagong, Kumira-4318, Chittagong, Bangladesh \\ ${ }^{2}$ Department of Business Administration, Kulliyyah of Economics and Management \\ Sciences, International Islamic University Malaysia, Jalan Gombak, \\ 53100 Kuala Lumpur, Malaysia \\ ${ }^{3}$ International Institute of Islamic Civilisation and Malay World, \\ International Islamic University Malaysia, 50480 Kuala Lumpur, Malaysia \\ ${ }^{4}$ Department of Quran and Sunnah Studies, Kulliyyah of Islamic Revealed Knowledge \\ and Human Sciences, International Islamic University Malaysia, \\ 53100 Kuala Lumpur, Malaysia \\ *Corresponding author: rislam@iium.edu.my
}

Published online: 27 June 2019

To cite this article: Afrin, A.B., Islam, R., Fontaine, R.A.H., Ali, M.Y., and Rahman, M. (2019). A new model of continuous improvement in total quality management from an Islamic perspective. Asian Academy of Management Journal, 24(1), 129-149. https://doi.org/10.21315/aamj2019.24.1.6

To link to this article: https://doi.org/10.21315/aamj2019.24.1.6

\begin{abstract}
Continuous improvement in products/services is a vital element of total quality management (TQM). To strengthen competitive advantage in the market, organisations must continuously improve quality of products and services. Whether this process is termed as Jidoka, Kaizen, PDSA, 5-S, Six Sigma, or JIT, the purpose is to continually improve product/service quality or process quality. However, these models focus solely on mundane benefits. Developing a model of continuous improvement from an Islamic perspective is the major objective of this study. By nature, the study is an exploratory one and theoretically based on library research and is rooted in the Qur'ān and Sunnah. The major outcome of this research is development of a new model of continuous improvement, named NAMS cycle. This cycle is composed of four inter-related components: al-Nìyyah bi al-Ikhlās, al'Amal, al-Muhāsaba, and al-Ṣhukr. Having the initial letters of the components the model
\end{abstract}

(C) Asian Academy of Management and Penerbit Universiti Sains Malaysia, 2019. This work is licensed under the terms of the Creative Commons Attribution (CC BY) (http://creativecommons. org/licenses/by/4.0/). 
is named. In turn, each component consists of a number of elements, for example al-Niyyah bi al-Ikhlās consists of intention, objectives, and planning. Organisations have to fulfil two prerequisites for successful implementation of the model in their premises which are top management commitment and strongly motivated work team.

Keywords: continuous improvement, PDSA cycle, Islamic approach to continuous improvement, principles of TQM, NAMS cycle

\section{INTRODUCTION}

After World War II when Japan was struggling to survive, W. Edwards Deming and Joseph M. Juran came up with the concept of "quality movement" which resulted in "total quality management" (TQM). Now, TQM is not simply a concept, rather a philosophy. Dilworth (1993) stated that "total quality" (TQ) is total in time, it never ends because there is no level of quality that is "good enough". This statement indicates the importance of TQ culture of continuous improvement. Continuous improvement (CI) is considered as a vital one among the principles of TQM (Imai, 1986). CI is an essential requirement for any product that a firm produces or any process through which an organisation delivers services to its customers and clients (Ahbabi \& Alshawi, 2015; Plenert, 2012). A number of studies have been conducted on many issues of CI and still studies are being conducted by many researchers or group of researchers.

Continuous improvement models developed by non-Muslim scholars are foreign to the Muslim state of mind, rooted in the concept of worldly gain (Osman, 2005). So, there is a need to develop a management model suitable for the Muslim culture. It may be noted that culture and religion are not the same, but all the cultures and social systems are rooted into religions (Al-Faruqi, 1992). Muslim culture refers to the general customs, traditions, and belief of Muslim ummah. Muslims believe in the Oneness of God, the Holy Scriptures, and all the Prophets from Adam AS to Muhammad SAW without discrimination, the Day of Judgement, etc. Culturally speaking, commonalities include giving charity, expectation to maintain a balance between responsibility to the Creator and to their fellow human beings focusing particularly on the care and love for the elderly. Islam is also seen as an all-inclusive way of life rather than a strict exclusive religious code because of its focus on balancing personal and public life. Some local customs and traditions, which are not contradictory to Islamic sharia principles, are also the part of the culture of that particular Muslim community. For example, dress style and food habit of Muslim communities in different countries are their indigenous culture. 
The models that will be developed must be based on knowledge from the revealed sources as well as knowledge about today's business environment (Ahmad, 2009). The conventional management approaches and models are developed based on the pertinent knowledge of management by relating it to managerial jobs (Weihrich, 2005). There are no guiding principles derived from religion and faith in conventional management. On the other hand, Islamic models and approaches to management are based on and/or guided by Islamic sharia principles (Loqman \& Bulbul, 2011). Along with some distinguishing features, accountability to Allāh SWT in the life Hereafter makes the Islamic management different from others (Mohiuddin, 2006).

\section{LITERATURE REVIEW}

\section{Conventional Approaches to Continuous Quality Improvement}

The term "continuous improvement" is used widely to compete successfully in the market. Masaaki Imai first used the term in 1986 (Murray \& Chapman, 2003) but the concept was used in the 1930s when Walter Shewhart oriented three-step scientific process of improving quality (Shewhart, 1939). He later revised this idea into a cyclical concept. Shewhart (1939, p. 45) wrote:

These three steps must go in a circle instead of in a straight-line. It may be helpful to think of the three steps in the mass production process as steps in the scientific method ... The three steps constitute a dynamic scientific process of acquiring knowledge.

His concept evolved into what became known as the Shewhart cycle. CI is also observed in Juran Quality Trilogy - quality planning, quality control, and quality improvement. Deming closely reviewed Shewhart's works. At the age of 39, he edited a series of lectures delivered by Shewhart to the US Department of Agriculture and eventually became the basis of Shewhart's 1939 book. Deming presented a new version of the cycle in 1950 during an eight-day landmark visit to Japan (Deming, 1950, 1986, 1993).

In his new version of the cycle, Deming emphasised constant interaction among the four steps of design, production, sales, and research. He highlighted that these steps should be rotated, keeping quality of product and service as the main focus. This new version is referred to as the Deming cycle or PDSA (Plan-Do-StudyAct) cycle. Deming described it as a flow diagram for learning and improvement of a product or a process (Moen \& Norman, 2009). Along with PDSA cycle, 
many other approaches/methodologies have been evolved to implement the CI in practice. The most practising approaches are Kaizen, 5-S, just-in-time (JIT), lean operation, DMAIC (Define-Measure-Analyse-Improve-Control) Six Sigma, Lean Six Sigma (LSS), etc. Six Sigma and LSS can provide effective solutions to improving the quality and processes in a service provider organisation while simultaneously creating a cultural change within the organisation by involving everyone associated with the process being evaluated (Honda, Bernardo, Mateus Cecílio Gerolamo, \& Davis, 2018).

LSS can be applied for the eradication of waste applying DMAIC principle. This application emphasises on CI processes, customer satisfaction, and better financial performance for organisations. Many other authors suggest for another integrated approach of CI such as BSC Six Sigma (BSC stands for Balanced Score Card) (Heavey, Ledwith, \& Murphy, 2014).

Quality Control Circle (QCC) is another effective tool for process improvement. The firms that operate a QCC, disseminate QCC experiences across departments within the firm, and share QCC experiences with customers and suppliers (Intalar, Jeenanunta, Rittippant, Chongphaisal, \& Komolavanij, 2018).

Besides the above approaches of CI, other approaches are practised in organisations to improve quality. Some studies showed that different approaches to CI are equally effective in driving improvements in both technical and social systems, even though there are significant differences in the project size, type, location, and industrial sector (Jin \& Doolen, 2014). Another study found out that the success of the use of CI approaches depends on the culture of the organisation and the capability of the managers and leaders to implement those approaches effectively (Robinson \& Phuong, 2015). Robinson and Phuong (2015) suggested that every unique culture of the organisation should follow unique approaches of CI to ensure improvement in quality. Wahid and Ismail (2017) conducted a study to identify the antecedents for relationship quality model that would help the organisations to increase the quality of their services. They found out that positive emotional expression (PEE) acts as the antecedent to relationship quality (RQ) while RQ is positively linked to the word-of-mouth (WOM) and share-of-purchase (SOP) outcomes that helps the organisations to attract and satisfy the customers through quality services (Wahid \& Ismail, 2017).

\section{An Islamic Approach to Continuous Quality Improvement}

In Islam, quality management is not overlooked. Quality is very much emphasised in the teaching of Islam. Allāh SWT wants people to do all their works with best 
of the quality and $\mathrm{He}$ will judge them on the basis of the quality of their deeds. ${ }^{1}$ Thus, to perform every task in the best possible way is a religious obligation for the Muslims. Believing in only one God (al-Tawhīd) makes easy to ensure the quality in our lifelong activities. To explain the term al-Tawhìd, Imam al-Ghazali said "there is no God but Allāh SwT" is the root of al-Tawhìd. To describe the uniqueness of Allāh swT, Imam al-Ghazali said:

He is without body and form. ... Nothing is like Him and He is not like anything ... Everything is in His grasp ... He is Ever-living, All-powerful, Almighty, the great Destroyer. He is free from faults and failures, slumber, sleep, disease, death ... He is unique in creation and unrivalled in ever new creations ... His power and might are above counting (Ghazali, 1993, p. 90).

Tawhīd literally means "making one" or "asserting oneness" (Gibb \& Kramers, 2001). In consequence, it is applied theologically to the oneness (wahdāniya, tawaḥhud) of Allāh SWT in all its meanings. Technically, "the science of Tawhīd and of the qualities" ("ilm al-Tawhìd wa 'l-șifät) is a synonym for "the science of kalām". Unity is far from being a simple idea. It may be internal or external; it may mean that there is no other God except Allāh SWT, who has no partner (sharīk); Allāh SWT is a Oneness in Himself; and He is the only being with real or absolute existence (al-hakk). All other beings having merely a contingent existence. Knowledge of this unity may be reached by the methods of systematic theology ('ilm) or by religious experience (ma'rifa, mushāhada). Again, it may be pure contemplation or philosophical speculation. In consequence, Tawhīd may mean simply "there is no god but Allāh" (SWT). As the absolute Truth (al-haqq), Allāh swT is the source of all other truths (Al-Faruqi, 1992). Al-Tawhìd affirms that the uniqueness Allāh SWT created man in the best of forms for the purpose of worshiping and serving Him. ${ }^{2}$ It also affirms that the purpose consists of man's Vicegerency for God on Earth. ${ }^{3}$ Al-Tawhìd tells us that God, being beneficent and purposive, did not create man in sport or in vain. ${ }^{4}$ In the Islamic code which unifies all mundane and other aspects of life in the normative bondage of the Islamic worldview, quality is of such importance that the merit of one's performance is judged by its quality more than quantity. Quality deserves the highest attention in management. This is because a low-quality management will be transmitted to the entire organisational system. A high-quality management, on the other hand, is expected to be reflected in the blood stream of the organisation nurturing high quality performance. For this reason, Islam emphasises on quality management (Ahmad, 2006). 
In Islam, quality is a process of positive changes for excellent performance in all human endeavours. It is a long-term process of continuous improvement. Every individual and organisation must work to show quality performance by following proper approaches and planning. Quality performance cannot be narrowly understood since the quality of the products and services must satisfy customer demands. From the Islamic perspective, an organisation must focus on "quality workers, effective leadership, good management, and appropriate structural set up as the four elements of quality and productivity" (Sadeq, 1996). It is also the responsibility of an organisation to meet the expectations of the customers in the best possible way and with best quality products and/or services. This responsibility is evident in some hadiths. ${ }^{5}$

A poor-quality performance may bring an adverse outcome. For example, salah (prayer) has been ordained for Muslims in many ayats (sentences) of the Qur'ān and sunnah, but a severe consequence has been declared for those who offer a poor quality salah. ${ }^{6}$ Similarly, sawm (fasting) has been made obligatory for Muslims. ${ }^{7}$ Valuable benefits of sawm have been mentioned. ${ }^{8}$ However, the sawm becomes useless when it is not of high quality. ${ }^{9}$ Therefore, excellence is a requirement not only in big matters but also in matters like slaughtering an animal. ${ }^{10}$ In the Islamic history, it is abound that when the manpower of a state or an organisation were khalis (more dedicated in their 'ibādah, worshiping/obeying Allāh swT), their success was obvious, for example, the Battle of Badr. The number of Muslim soldiers was very few against the non-Muslim soldiers, but the Muslims won. On the other hand, during the Battle of Uhud, the Muslim soldiers were big in numbers, but they failed. The reason behind that failure was some of the Muslim soldiers were poor in their personal 'ibädah. In the same vain, in an organisation, individuals are occupying a very significant place in the process of producing products and/or providing services. When the individuals will be khalis, it will reflect their performances in the organisation. It is said in the Qur'ān that salah keeps a person (worshipper) away from committing all types of evil deeds. So, if the individuals are very much committed to their personal 'ibādah and they do not commit evil deeds in their personal and organisational life, the quality of their performances will be praiseworthy (by the will of Allāh SWT).

\section{Continuous Improvement and Wastage in Islam}

Wastage in any of the resources is one of the causes of poor quality. These happen both in our personal activities and the activities through which we serve others. Islam prohibits any form of wastage of resources (niyamah). A Muslim must make every effort to remove wastage around him, at home, workplace, or in society, even when faced with confrontation. A common example would be to control the 
use of water, food, and electricity according to needs. Wastage of resources such as material in the workplace, man-hours, machine-hours, human potential, and time should also be minimised and properly utilised. While $100 \%$ elimination is not possible, it should nevertheless be an aim through continuous effort. Muslims should find this easier than others because they have been clearly instructed in the Holy Qur'ān to avoid wastage: "For the wasteful are the brothers of Satan; and Satan is ungrateful to his Lord" (surah al-Isra, 17:27). So, to minimise wastage in every task is a religious command for a Muslim.

Being steadfast in every action is also essential to improve. Allāh swT says, "You who believe, be steadfast, more steadfast than others; be ready; always be mindful of God so that you may prosper" (surah ali-Imran, 3:200). There are also some sayings of Prophet Muhammad sAW regarding steadfastness in every action.

Sayyidina Ali RA told that if one's today's activities are not better than those of yesterdays, he/she is not a good Muslim (Alam, 1983). So, it is the obligation for every Muslim to try again and again to develop his/her daily activities in both personal life and social/organisational life and it is a basic requirement in Islam.

The contemporary literatures on quality management from Islamic perspective show that most of the works are on the elaboration on a list of values embedded in the practice of quality management and there are some improvements in developing some models of quality management. For example, Musa and Salleh (2005) proposed a model of an Islamic total quality. Jabnoun (2008) developed 'Umar's TQM Control Process. It shows that some improvements have been made in developing models of TQM, but no model has yet been developed on CI in TQM from Islamic perspective. Here is a research gap and the present study has been conducted to minimise this gap.

\section{OBJECTIVE AND METHODOLOGY OF THE STUDY}

The main purpose of the present study is to develop a new model of CI in TQM from Islamic perspective through an exploratory qualitative research based on extensive review of published literatures, relevant verses from the Holy Qur'ān, principles and traditions of Prophet Muhammad saw, and the sayings and practices of the companions of Prophet SAW and other Muslim scholars. The traditional Islamic epistemology (theory of knowledge) provides all the necessary safeguards against all kinds of philosophical deviations (Bakar, 2008). Islam is the religion of unity (al-Tawhi d). It espouses the idea of the hierarchy and unity of knowledge and of modes of knowing. According to Islam, man has been equipped with all 
the necessary facilities of knowing which enable him to know all that he needs to know. ${ }^{11}$ But only one source of knowledge is Allāh swT and man cannot know anything from those without His willingness. ${ }^{12}$

Therefore, the epistemological paradigm of this particular study is based on the idea of unity (al-Tawhìd). The fundamental epistemological foundations of the al-Tawhìd worldview are the Qur'ān and the sunnah. The secondary epistemic medium is the contributions of scholars in Islam which is used to interpret the doctrines of the divine law in the light of the Qur'ān and the sunnah. Learning systems governed by the episteme of unity of knowledge, form the foundation of every Islamic methodological inquiry and application. Hence, to be successful in the life Hereafter and to please Allāh SWT is the ontological standpoint of this particular study.

To develop the model, the researchers have collected data through extensive literature review and focus group discussions (FGD). Initially, a conceptual model (Afrin \& Islam, 2018) was developed based on the components along with their constructs extracted from extensive literature review. In that model, the researchers showed two phases where the Phase 1 consisted of the main components and Phase 2 consisted of the constructs of the components (expansion of Phase 1). After developing the conceptual model, the researchers arranged a FGD. They invited 18 academics and practitioners who have strong background of Islamic sharia knowledge and knowledge of quality management as well. They were invited through e-mails and the researchers also talked with them directly over telephone. The invitees were selected by using purposive sampling technique. From among the invitees, 11 attended and actively participated in the FGD. The meeting continued for about two hours. Within this time, the FGD participants contributed significantly by proving their valuable suggestions and comments on that conceptual model for its improvement. Most of them talked about the values to be inculcated into the manpower of the organisation and few of them suggested to revise the model. Based on their valuable comments and suggestions, the researchers revised the conceptual model. Some of the participants were not interested to mention their names and affiliations, for this reason, the researchers named them as P1, P2, P3 up to P11. 


\section{RESULTS AND DISCUSSION}

\section{The New Model of CI from an Islamic Perspective}

Because the vision of a Muslim is to serve Allāh swT and to please Him through actions in this life, the mission statement consists of 'ibādah or worship Allāh SWT, and the overriding objective of every activity will be to please Him by obeying the instructions of the Qur'ān and sunnah. It is equally significant for Muslims as an individual and/or as an organisation. Having this objective in mind, we have developed a CI model named as NAMS cycle to serve the nation to continuously improve the quality of their activities.

Initially, the first two authors of the present paper developed a conceptual model (Afrin \& Islam, 2018) based on extensive literature review, and to finalise the model they conducted a FGD. FGD was started with the collective recitation of surah al-Fatihah. Then one of the authors introduced the other authors to the participants. After introducing, another co-author presented the conceptual model with some description in front of the participants. After that the floor was open for all the participants to give their constructive criticisms, comments, and suggestions to improve the model. The participants were sharing their ideas one by one and others were also participating in the discussions. It was helpful for the researchers to record all the conversations in an audio record. Later, we translated the audio record into transcripts manually and then analyse the data by following the six steps of qualitative data analysis method (Creswell, 2010).

Because most of the participants in the FGD talked about the values to be inculcated into the manpower of the organisation and few of them suggested to revise the model. The researchers were interested only on the development or modification of the conceptual model. For this reason, the participants were narrowed to P8 and P9. P8 told:

I am not sure about the translation. I see the use of satisfaction of Allāh swt in your thesis, right? I am not sure how to pass, but for me, when you say satisfaction, it seems to mean that there are, that may be my interpretation, some needs, the needs to be satisfied, right? So, of course Allāh SWT, we know, He is perfect. So, there is no question of satisfaction. So, I am not sure, so many cases, for example, pleasing of Allāh or, Allāh's acceptance or, what would be the other thing? 
When she was talking about the phrase "Pleasing of Allāh swT" most of the participants agreed with her comment. As there is no harm to use the phrase, the researchers replaced "Satisfaction of Allāh SWT" by "Pleasing of Allāh SWT". She again said:

And then the other question is, is there any specific reason why you put there the first phase and second phase? Because, I am not talking, he was saying that this central part that you have and of course if you have complete all tasks, in shaa Allah, there will be Rida Allah, right? So, I am not sure about that, actually just marge it together to have one model. Okay, when you are showing the first phase and then second phase, my assumption is you have two, number one phase and then number two. So, if you consider that then, ok.

So, the researchers tried to tie all the components with their respective constructs in a single figure named NAMS cycle. P8 further said: "Maybe, in your discussion, further clarification you put from Islamic perspective. For example, I see the SWOT analysis there, that is very conventional". P9 said: "Therefore, we look at the Islamic perspective. So, I mean, this is a simple something that I am also trying to come up with our professors have asked to brainstorm this idea".

On the basis of their comments, the researchers studied again on the same and used QDFT [al-Niqāt al-Quwwah (strengths), al-Niqāt al-D 'afi (weaknesses), al-Furașun (opportunities), and al-Tahdīdātun (threats)] analysis instead of SWOT analysis under the constructs of al-Muhāsaba (constructive criticism). Figure 1 shows the modified model of NAMS cycle while the following sections detail its various components with their constructs.

The cycle starts with al-Niyyah bi al-Ikhlās and followed by al-Amal, $a l-M u h a \bar{a} a b a$, and $a l-S h u k r$, and returning to al-Nìyyah. In every action, people need to think critically whether their activities are like 'ibädah, or are being done according to Islamic sharia and to please Allāh swT only. In general, these steps are very suitable for individual practices. But, it should be remembered that an organisation is built and run by individuals. So, if individuals can improve their performances in organisations by following these steps effectively and efficiently, organisations/groups will improve accordingly. In every step, organisations need to do the activities described in Figure 1. 


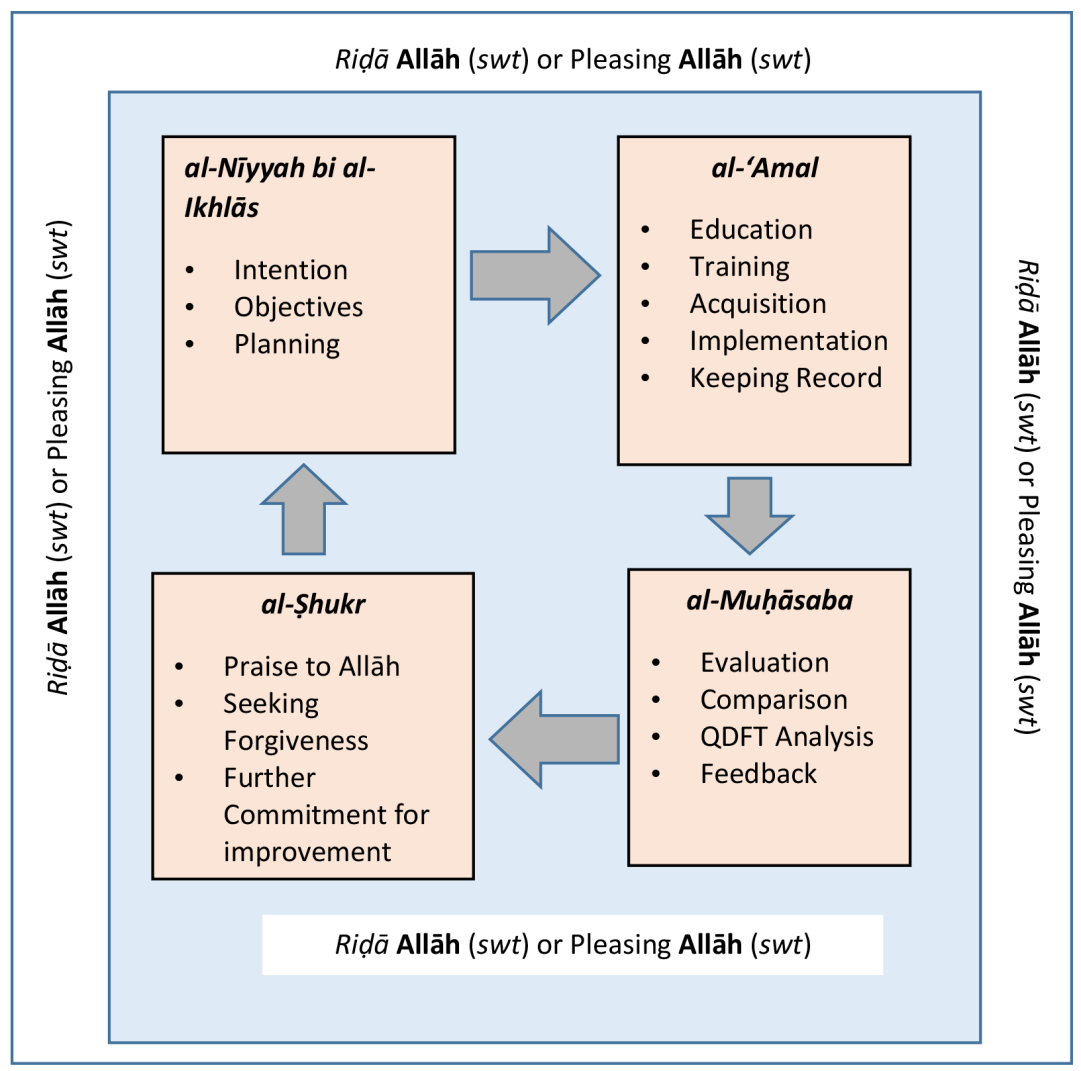

Figure 1. NAMS cycle

\section{Al-Nīyah bil Ikhlās}

The first component of the NAMS cycle is al-Niyah bil Ikhlās which means for Muslims every action will be started with a clear or pure intention of pleasing Allāh swT by achieving some specific objectives. This component includes:

\section{Intention (nīyah)}

In Islam, the initial stage of doing any task is to clarify the niyah (intention behind the action). The doer must be honest, clear, and pure about the niyah, because the result of every task depends on the doer's niyah". ${ }^{13}$ The niyah of an organisation reflects in its vision and mission. The highest principle of al-Tawhì is that whatever a Muslim will do, will do only for pleasing Allāh swT (see the Tafsir of al-Lail, 92:20 and surah al-Baqarah, 2:272). 
Like an individual, an organisation must have good intention to serve the people by producing halal products and services with fair prices and without making any harm to the customers. At this stage of the newly developed model, the organisation needs to fix the noble vision of pleasing Allāh swT, the Creator and the Owner of the whole universe, the mission of the organisation, and to set the activities that will be treated as 'ibādah to Allāh swT and also fix an intention of taking initiatives to improve the quality of their activities, products and/or, services.

\section{Objectives (al-ahdaaf)}

According to the niyah, the doer/decision maker will have to set objectives to be achieved through organisational activities. These objectives indicate the destination of any task. To describe objectives, Sayyidina Ali RA said: "The objective of the clouds is not the rain, rather it is the fruits to be produced" (Jabnoun, 1994). The objective of fasting is to learn self-restraint. ${ }^{14}$ If Allāh swt wanted, He could have easily created man and sent him on earth, but He did not do so. He announced His intention of creating man in front of the angels and stated His objective to send him on earth (surah al-Baqarah, 2:30). Here is a clear indication of setting clear and specific objectives as the precedence of intention which can bring falah (welfare) for mankind.

When a Muslim intends to do any task, the objectives should be clearly specified and well known to the doer. At this stage, the organisation must set the specific objectives of making any improvement in quality while at the same time having the intention to please Allāh swT through serving customers with better quality.

\section{Planning (takhteet)}

Planning wisely is an important task in Islam. The Prophet Muhammad SAW lived a planned and rational life. The Qur'ān tells us that Allāh swT created this universe according to His plan. Allāh swT loves those actions which are carried out thoroughly and with perfection (Ahmad, 2006). In the same vein, the pathway of accomplishing a task in an organisation should be clearly stated. Duties and responsibilities will be assigned properly, and persons should be authorised according to the nature and requirement of the assigned task. ${ }^{15}$

At this planning stage, the organisation must clearly state the type of improvement that will be made, how much will it be made, where it will be, who will be responsible to do that, when the improvement will be done, and how much costs will be allocated for that. 


\section{Al-'Amal al-Takhțit (Implementation of Plans)}

Al-'Amal means actions having religious motivation. In this model, al-'Amal consists of some constructs or actions which should be integrated and justified by 'ibādah as described in the following sections:

\section{Education (al-Ta'lim)}

After proper planning, the next step is to inform people their duties and responsibilities and delegate the authority to complete their tasks. At the beginning of the nobuwah (prophethood), Prophet Muhammad saw was directly educated by Allāh swT through Jibreel As. It is also evident in surah al-Baqarah (2:31-34) how Allāh swT educate man before giving any responsibility. These incidents teach us that whenever responsibility is given, the person must be educated accordingly and be taught on how the duties and responsibilities can be executed to ensure the improvement of quality.

\section{Training (al-Tarbiyya $h$ )}

Having duties, responsibilities, and power, people need to learn how to operate the relevant tools, techniques, and use the technology to perform their jobs. Employee training is essential to keep his/her knowledge updated and sharpening the aptitude by equipping themselves with the necessary skills required to thrive in the present day competitive working environment. After creating Adam AS and his company, Allāh swT allowed them to stay in the Jannah to train them how to fight with Satan (surah al-Baqarah, 2:31-34).

The Angel Jibreel as taught Prophet Muhammad saw how to pray (salah) by praying with him. Prophet Muhammad saw then requested his followers to follow his example in prayer. For the Muslim ummah, there is one month out of 12 months in a year, called Ramadan. This holy month is observed by Muslims worldwide as a month of fasting and as training month to increase their taqwa (Allāh SWT consciousness). In such ways, training is emphasised in Islam to carry out tasks effectively and efficiently.

In the newly developed model, at this stage the organisations will have to arrange some required training sessions for the employees to increase their skills and capabilities to implement the plan successfully. 


\section{Acquisition (al-Iktisāb)}

After proper education and training, people need to be provided the required equipment and materials to accomplish their tasks. The organisation must acquire those quality equipment and materials from available sources to do the tasks efficiently. In the life of Prophet Muhammad SAw, we can see that in any crisis, he used to accumulate the commodities and distribute them among the seekers. Specifically, before starting any battle, he used to accumulate the materials needed to conduct the battle and distributed them among the soldiers. This indicates that, in Islam, acquisition and distribution are emphasised. To enhance quality, the smooth flow of required resources is vital. The resources should be adequate but not excessive that they may cause wastage, because wastage is prohibited in Islam (surah al-Isra, 17:27).

\section{Implementation (al-Tațīq)}

At this step, the doer must be careful because the result of any task depends upon the sincerity and efficiency of doing the task. The Qur'ān states, “and do good deeds that you may prosper" (surah al-Hajj, 22:77). A number of related verses in the Qur'ān and hadiths state that if anyone has good intention, he/she will get one reward and if he/she implements that in action, will get double. However, it should be remembered that the outcomes of the implementation of any decision depends upon Allāh swT (surah al-Imran, 3:159).

\section{Record keeping (at-Tasjīl)}

Every task must be recorded, so that nothing will be missed at the time of counting and evaluating. It will help to audit properly, to reward, or punish the doer rightly. In many places of the Holy Qur'ān, Allāh swT has mentioned about record keeping as a document for fair judgment (surahs al-Infitr, 82: 10-12; al-Zilzal, 99:6-8; Q'af, 50:17-18; al-'Imran, 3:181; an-Nisā, 4:81; Yunus, 10:21,61; Hud, 11:16; al-Isra', 17:14,58,71). Every individual should keep his/her own record so that he/she can realise the status of his/her activities and make improvement on a daily basis. Along with individuals, organisations also have to record the activities of their employees, so they can appraise their employees' performance justly.

\section{Al-Muḥāsaba (Self-Accounting)}

The Arabic verbal noun Muhāsaba means accounting. In mystical theology muhāasabat al-nafs means "inward accounting, spiritual accounting". Muhāsaba is the learned doublet of hisab. 'Umar said, "Take account of your souls yourselves 
(hasibu anfusakum) before account is made of them, weigh them before they are weighed (in the divine balance, al-Mizan), and prepare yourselves for the supreme examination" (hadith Tirmidhi, Sunan, 38). In this model, Muhāsaba consists of the following factors:

\section{Measurement and evaluation (al-Taqeem)}

In this step, the recorded results will be collected and examined qualitatively and quantitatively. Allāh swT declared in the Holy Qur'ān that every atom of good and bad deeds will be evaluated on the Day of Judgement and nobody will be exempted (surah al-Zilzāl, 99:6-8; surah al-Kahf, 18:49). In the organisations people will evaluate their own works and superiors will evaluate the subordinates' works justly. A structured format may be used here to evaluate performance of the employees.

\section{Comparison and constructive analysis (al-Muqārana wa Taḥlīl al-Binā)}

The outcomes will be compared with the set objectives and plans. Analysis should be constructive and from both parties. In Islam, everything is Allāh's swT concern and falls within the realm of the religious imperatives (surah al-Tawbah, 9:71; surah al-Maīdah, 5:2; hadith al-Tirmidhi, 30:18:1936). In every sphere of life, Muslims should cooperate in good deeds and improve their activities through constructive analysis. In this way, Muslims can improve the quality of their tasks in personal life as well as social and organisational life.

\section{Identifying strong and weak points (Taḥdid Nuqat Qawiyya wa Da ifah)}

QDFT analysis is needed to point out the strengths that will help organisations achieve their goals. A proper and thorough QDFT analysis helps organisations strategically. At this stage, it should be remembered that all those points must be justified by "Pleasing Allāh SWT". The tasks which are helpful to please Allāh SWT are the strengths. The features needed to please Him are considered as opportunities, and situations which are contradictory to pleasing Allāh SWT and outside the control of the organisation are treated as threats. Organisations should be very careful about these matters so that they can take corrective measures as needed to improve their quality.

\section{Feedback (Rudūd al-Fà l)}

Feedback plays an extremely important role in continuous improvement. Every person has a right to know what he/she has done. In an organisational context, if 
they do any good, they should be rewarded; and if there is any wrong, they may need counselling and mentoring to improve the quality of their tasks. Nobody is responsible for the faults of others (surah al-Nazm, 53:38-39; surah al-Infitr, 82:5). Therefore, the feedback should be fare and in time. A fare and timely feedback motivates the employees to do better in future.

\section{Al-Ṣhukr (Thankfulness)}

Al-Shukr is an Arabic word which denotes the meaning of thankfulness, gratitude, or acknowledgment by humans. It is one of the highly esteemed virtues in Islam. Al-Shukr consists of some components/actions to construct the model as stated below:

\section{Praise to Allāh swt (al-Șhukr al-Allāh SWT)}

Șhukr means giving thanks to Allāh swT. In good or bad situations, a Muslim always thanks Allāh swT. With anything good, they say "Alhamdulillāh" (all praises due to Allāh SWT) and in facing difficulties they say "Innā lillāhi wa innā ilaihi rājiūn" (indeed we belong to Allāh swT and we shall return to Him).

In organisations, there should be a culture of șukr to Allāh swT along with thanking their peers and superiors. If anything is good, the culture should be to say "Alhamdulillāh", and "jazak Allāh al khair" (May Allāh swT gives you better reward). This culture helps the employees to remember Allāh swT in all the time and their relationship will be closer among each other and also with Allāh swT.

\section{Seeking forgiveness (al-Istiqhfär)}

Al-Istiqhfär means to seek pardon for any mistake - intentional or unintentional. It demands that the person feels the mistake by heart and commit not to repeat the same mistake. Tawbah urges the individual to do more good work to compensate for the wrong he/she has done (surah Anam, 6:54).

According to the Qur'ānic description, most prophets were blessed by Allāh SWT because they made tawbah and istiqhfär. There are three conditions of accepting tawbah: (1) feeling remorse, (2) feeling guilty, and (3) making a commitment not to repeat the mistake in the future. People are also encouraged to recite istiqhfär for any unknown mistake (surah al-Nasr, 110:1-3). According to Islamic norms, istiqhfär or seeking forgiveness is not only for committing mistakes, but when there is any victory, Muslims need to praise Allāh swt for the victory and at the same time, they need to seek forgiveness if there is any mistake (unknown to them). 
They have to build a culture to practice istiqhfär so that people do not commit the same mistake repeatedly. In this way, the individuals as well as the organisations will be able to improve the quality of their performance continuously.

\section{Commitment to future improvement (al-Iltijām bi Tahsīn al-Mustaqbil)}

After evaluating all the outcomes and situations, the organisations have to take corrective measures to overcome the drawbacks. Top management should be very committed to future improvement of the organisation and they must do all the necessary to ensure such improvement. Along with the organisation, individuals also must be committed to improve their performances and the quality of their actions. All of these require a good niyyah indicating that the process returns to the starting point of the cycle.

\section{Prerequisites for Successful Implementation of the Newly-Developed Model of CI}

After developing the model, the next question is how to implement this. As P7 asked, "Generally ..., this model, I am wondering how you want to apply this model?" To respond to this question, we have proposed two prerequisites that an organisation needs to fulfil for successful implementation of the newly developed NAMS Cycle. These prerequisites are stated below:

1. Top management must be committed to implement the model in their organisation and will have to provide all sorts of supports.

2. A strongly motivated work team should be developed by providing necessary training. The Islamic and professional values which should be inculcated among them during training are tawhìd (oneness of Allāh swT) and freedom from tyranny, taqwa (God consciousness), istiqamah (steadfastness), ikhlas (absolute devotion), iḥsān (perfection or excellence), abstaining from harām (prohibition in Islam), unity of purpose, humbleness, trust, brotherhood, dignity and respect for other, cost efficiency, time efficiency, quality/diligence, flexibility, fairness, cooperation, long-term orientation, discipline, participative management, innovativeness/eagerness to learn and to share knowledge, responsibility and accountability, openness, justice, optimism, consistence, patience, thankfulness, and tawakkal (executing a task and putting trust in Allāh SWT for its result). 


\section{CONCLUSION}

To make the conventional approach of continuous improvement more fruitful, PDCA (Plan-Do-Check-Act)/PDSA cycle, Kaizen approach, JIT management, 5-S, and DMAIC Six-Sigma have been developed and the study is ongoing to improve the approaches. Organisations are concerned with learning and practising these approaches to improve quality. In Islamic approach, thus far no supporting model has been developed regarding continuous improvement practices in organisations. In the present study, the researchers have taken an initiative to develop a model of continuous improvement in TQM from Islamic point of view, named as NAMS cycle, which is an inseparable part of sharia compliance management. After developing the model, the next step is to test the practicability of this model in organisations. Future research is needed to develop implementation guidelines and evaluate the merits of the model.

\section{ACKNOWLEDGEMENTS}

The authors would like to express and extend their heartfelt thanks and gratitude to all the participants in the FGD meeting and acknowledge their contributions to modify and improve the NAMS cycle. The authors also like to thank all the reviewers and editors of this paper for their valuable comments and suggestions to make the paper better in terms of quality and presentation.

\section{NOTES}

1. "He, who created death and life to test you whom of you is best in deed" (surah alMulk, 67:2).

2. "I have only created Jinns and men, that they may serve Me" (surah al-Aldzaariyat, 51:56). "We have indeed created man in the best of moulds" (surah at-Tiin, 95:4).

3. Behold, thy Lord said to the angels: "I will create a vicegerent on earth". They said: "Wilt Thou place therein one who will make mischief therein and shed blood? Whilst we do celebrate Thy praises and glorify Thy holy [name]?" He said: "I know what ye know not" (surah al-Baqarah, 2:30).

4. "Did ye then think that We had created you in jest, and that ye would not be brought back to Us [for account]?" (surah al-Mu'minun, 23:11). "Not for [idle] sport did We create the heavens and the earth and all that is between!" (surah al-Anbiyaa', 21:16).

5. The Prophet saw said, "None of you will have faith till he wishes for his [Muslim] brother what he likes for himself" (hadith al-Bukhari, 1:2:12). "A Muslim is the one who avoids harming Muslims with his tongue and hands" (hadith al-Bukhari, 1:2:9). 
6. "So, woe to those who pray, but are unmindful of their prayers" (surah Al-Ma'un, 107:4-5).

7. "O ye who believe! Fasting is prescribed to you as it was prescribed to those before you, that ye may [learn] self-restraint" (surah al-Baqarah, 2:183).

8. Prophet SAW said, "Allāh SWT said, 'All the deeds of Adam's sons [people] are for them, except fasting which is for Me, and I will give the reward for it" (hadith alBukhari 3:31:128).

9. The Prophet SAW also said, "Whoever does not give up forged speech and evil actions, Allāh SwT is not in need of his leaving his food and drink [i.e., Allāh swT will not accept his fasting]" (hadith al-Bukhari, 3:31:127).

10. Prophet SAW said, "Allāh swt has decreed good for everything. When you kill, do it in the best way; and when you slaughter [an animal for sacrifice], do it in the best way. So, every one of you should sharpen your knife and let the slaughtered animal die comfortably" (hadith al-Muslim, 21:11:4810).

11. "He, Who has made everything which He has created most good ... And He gave you [the faculties of] hearing and sight and feeling [and understanding]: little thanks do ye give!" (surah as-Sajdah, 32:7-9).

12. "Allāh swT! There is no god but He, - the Living, the Self-subsisting, ... He knoweth what [appeared to His creatures as] before or after or behind them. Nor shall they compass aught of His knowledge except as He willeth" (surah al-Baqarah, 2:255).

13. 'Umar bin Al-Khattab RA narrated that he heard Allāh's swt Apostle sAw saying: "The reward of deeds depends upon the intentions and every person will get the reward according to what he has intended. So, whoever emigrated for worldly benefits or for a woman to marry, his emigration was for what he emigrated for" (hadith al-Bukhari, $1: 1: 1)$.

Sayyidina Abu Bakra RA said: "I have heard Allāh's swT Apostle sAw saying, 'When two Muslims fight (meet) each other with their swords, both the murderer as well as the murdered will go to the Hell-fire'. I said, 'O Allāh's swt Apostle sAw! It is all right for the murderer but what about the murdered one?' Allāh's swT Apostle sAw replied, 'He surely had the intention to kill his companion'" (hadith al-Bukhari, 1:2:30).

14. "O ye who believe! Fasting is prescribed to you as it was prescribed to those before you, that ye may [learn] self-restraint" (surah al-Baqarah, 2:183).

15. Sayyidina Ali RA once said that plan your work daily, because every day comes with new concerns (Alam, 1983). About planned activity, Sayyidina Abdullah Ibn Umar Faruq RA said that you should do the earthly activities in such a way that you will remain alive for ever and at the same time work for the hereafter in such a way that you will die soon (Jabnoun, 1994). 


\section{REFERENCES}

Afrin, A.B., \& Islam, R. (2018). A conceptual model of continuous improvement in total quality management from Islamic perspective. Australian Academy of Business and Economics Review, 4(1), 1-16.

Ahbabi, A.M., \& Alshawi, M. (2015). BIM for client organisations: A continuous improvement approach. Construction Innovation, 15(4), 402-408. https://doi. org/10.1108/ci-04-2015-0023

Ahmad, K. (2006). Management from Islamic perspective. Kuala Lumpur: IIUM Press.

Ahmad, K. (2009). Leadership and work motivation from the cross-cultural perspective. International Journal of Commerce and Management, 19(1), 72-84. https://doi. org/10.1108/10569210910939681

Al-Faruqi, I.R. (1992). Al-tawhid: Its implications for thought and life (2nd ed.). Virginia, USA: International Institution of Islamic Thought.

Alam, S. (1983). Letter to Malik Ibn Al-Harith from Ali-Ibn Abu Talib. Dhaka: Islamic Foundation.

Bakar, O. (2008). Tawhid and science: Islamic perspectives on religion and science (2nd ed.). Kuala Lumpur: ARAH Publications.

Creswell, J. (2010). Mapping the developing landscape of mixed methods research. In A. Tashakkori, \& C. Teddlie (Eds.), SAGE handbook of mixed methods in social \& behavioral research (pp. 45-68). California: Sage. https://doi. org/10.4135/9781506335193.n2

Deming, W.E. (1950). Elementary principles of the statistical control of quality. Tokyo: Nippon Kagaku Gijutsu Renmei.

Deming, W.E. (1986). Out of the crisis. Cambridge: Massachusetts Institute of Technology Press.

Deming, W.E. (1993). The new economics. Cambridge: Massachusetts Institute of Technology Press.

Dilworth, J. (1993). Production and operations management: Manufacturing and services. New York: McGraw Hill.

Ghazali, I. (1993). Ihya Ulim-Id-Din (translated by Fazl-Ul-Karim). Karachi: Darul-Ishaat. Gibb, H.A.R., \& Kramers, J.H. (2001). Concise encyclopaedia of Islam (4th impression). Boston: BRILL Academic Publishers Inc.

Heavey, C., Ledwith, A., \& Murphy, E. (2014). Introducing a new continuous improvement framework for increased organisational return on investment. The TQM Journal, 26(6), 594-609. https://doi.org/10.1108/tqm-06-2013-0065

Honda, A.C., Bernardo, V.Z., Mateus Cecílio Gerolamo, M.C., \& Davis, M.M. (2018). How lean six sigma principles improve hospital performance. Quality Management Journal, 25(2), 70-82. https://doi.org/10.1080/10686967.2018.1436349

Imai, M. (1986). Kaizen: The key to Japan's competitive success. New York: McGraw Hill.

Intalar, N., Jeenanunta, C., Rittippant, N., Chongphaisal, P., \& Komolavanij, S. (2018). The role of quality control circles on new product development: A case study of Thailand. Quality Management Journal, 25(3), 129-141. https://doi.org/10.1080 /10686967.2018.1474676 
Jabnoun, N. (1994). Management from an Islamic perspective. Kuala Lumpur: IIUM Press. Jabnoun, N. (2008). Islam and management (2nd ed.). Riyadh: International Islamic Publishing House.

Jin, H.W., \& Doolen, T.L. (2014). A comparison of Korean and US continuous improvement projects. International Journal of Productivity and Performance Management, 63(4), 384-405. https://doi.org/10.1108/ijppm-01-2013-0012

Loqman, M., \& Bulbul, A. (2011). Convergence and divergence between Islamic approach and conventional approach to management. In A. Khaliq, R. Islam, \& Y. Ismail (Eds.), Issues in Islamic management: Theories and practices (pp. 1-20). Kuala Lumpur: IIUM Press.

Moen, R.D., \& Norman, C.L. (2009). The history of the PDCA cycle. Paper presented at the Seventh Asian Network for Quality Congress, 13-19 October 2009, Tokyo.

Mohiuddin, G. (2006). Islamic management. Dhaka: University Grant Commission, Bangladesh.

Murray, P., \& Chapman, R. (2003). From continuous improvement to organisational learning: Developmental theory. The Learning Organisation, 10(5), 272-282. https://doi.org/10.1108/09696470310486629

Musa, M., \& Salleh, S.M.S.S.M. (2005). The elements of an ideal total quality from the Islamic perspective. In M. Musa, \& S.M.S.S.M. Salleh (Eds.), Quality standard from the Islamic perspective (pp. 149-172). Kuala Lumpur: IKIM.

Osman, M. (2005). Towards a universal integrated system ISI 2020. In M. Musa, \& S.M.S.S.M. Salleh (Eds.), Quality standard from the Islamic perspective (pp. 107-128). Kuala Lumpur: IKIM.

Plenert, H. (2012). Strategic continuous process improvement. New York: McGraw Hill.

Robinson, A.G., \& Phuong, A.N. (2015). Continuous improvement in Vietnam: Unique approaches for a unique culture. Journal of Asia Business Studies, 9(2), 195-211. https://doi.org/10.1108/jabs-11-2014-0093

Sadeq A.H.M. (1996). Quality management in the Islamic framework. In A.H.M. Sadeq, \& A.K. Ahmad, (Eds.), Quality management: Islamic perspectives (pp. 129-130). Kuala Lumpur: Leeds Publications.

Shewhart, W.A. (1939). Statistical methods from the viewpoint of quality control. Washington: US Department of Agriculture.

Wahid, N.A., \& Ismail, I. (2017). Identifying the antecedents for relationship quality model and its outcomes for priority banking customers in Indonesia. Asian Academy of Management Journal, 22(1), 131-150. https://doi.org/10.21315/aamj2017.22.1.6

Weihrich, H. (2005). Management: A global perspective. New Delhi: Tata McGraw Hill. 